\title{
LIFE-THREATENING VALPROATE OVERDOSE SUICESSFULLY TREATED WITH HAEMODIALYSIS
}

\author{
Julije MEŠTROVIĆ ${ }^{\text {, Tomislav FILIPOVIĆ }}$, Branka POLIĆ ${ }^{1}$, Luka STRIČEVIĆ ${ }^{1}$, Ante OMAZIĆ ${ }^{1}$, \\ Radenka KUZMANIĆ-ŠAMIJA ${ }^{3}$, and Joško MARKIĆ ${ }^{1}$
}

Department of Paediatrics, Paediatric Intensive Care Unit ${ }^{1}$, Department of Internal Medicine, Division of Nephrology ${ }^{2}$, Department of Paediatrics, Division of Neurology ${ }^{3}$, University Hospital Split, Split, Croatia

Received in June 2008

Accepted in October 2008

\begin{abstract}
Valproate (VPA) poisoning is an increasing clinical problem. The most common finding in VPA overdose is the depression of the central nervous system, which may progress to coma and death. This type of poisoning is difficult to treat, as no antidote exists. This report describes a case with a 16-year-old girl who poisoned herself with valproate. Initial treatment included naloxone, but she did not respond. She became comatose, with serum VPA concentration of $1320 \mu \mathrm{g} \mathrm{mL}^{-1}$. Three sessions of haemodialysis were performed, effectively eliminating VPA and decreasing the serum concentration. The patient regained consciousness and fully recovered.

To our knowledge, this is the highest serum VPA concentration reported by now in children aged 16 or less. Haemodialysis has proved to be the treatment of choice for life-threatening acute VPA overdose in children.
\end{abstract}

KEY WORDS: central nervous system depressants, intensive care, thrombocytopenia, toxicity

Valproate (VPA) is used as sodium valproate to manage childhood refractory epilepsy, behavioural disorders, and migraines. Cases of VPA overdosing have been on the rise (1). The most common finding is the central nervous system depression, and management is mainly symptomatic and supportive, including activated charcoal and naloxone (2). Haemodialysis, haemoperfusion, or both, have also been reported $(3,4)$. Here we report a case of a 16-year-old girl with VPA-induced coma who was successfully treated with haemodialysis.

\section{CASE PRESENTATION}

A 16-year-old girl was admitted to the Emergency Department of the University Hospital Split eight hours after ingesting $75 \mathrm{~g}\left(882 \mathrm{mg} \mathrm{kg}^{-1}\right)$ of VPA (enteric-coated formulation marketed as Apilepsin ${ }^{\circledR}$ ) in attempted suicide. On admission, her vital signs were: blood pressure $130 / 70 \mathrm{mmHg}$, pulse $100 \mathrm{~min}^{-1}$, and respiratory rate $25 \mathrm{~min}^{-1}$ and her Glasgow Coma Scale (GCS) score was 6. Initial blood analysis revealed serum VPA concentration of $1320 \mu \mathrm{g} \mathrm{mL}^{-1}$. Arterial blood gas analysis showed compensated metabolic acidosis, with an anion gap of $22.3 \mathrm{mmol} \mathrm{L}^{-1}$. Complete blood count, electrolytes, creatinine, and liver enzymes were normal. Two doses of naloxone, $0.9 \mathrm{mg}$ each, were given intravenously, but without notable improvement of her neurological status. Four hours after admission, she was in a deep coma (GCS 3). Breathing and circulation were stable, the patent airway was secured with the oropharyngeal (Guedel) airway, and there was no need for mechanical ventilation. Haemodialysis was considered the best possible therapeutic intervention at that moment, and the first session was immediately started through a double-lumen internal jugular vein using a NIPRO FB 130 TGA dialyser. 
After two hours of haemodialysis, VPA concentration decreased to $914 \mu \mathrm{g} \mathrm{mL}^{-1}$. Four hours later, it further decreased to $821 \mu \mathrm{g} \mathrm{mL}^{-1}$, but her neurological status did not improve. We therefore ran a CT scan of the brain, but it revealed no signs of cerebral oedema or abnormality. Serum chemistry showed evidence of a mild hypoglycaemia $\left(3.4 \mathrm{mmol} \mathrm{L}^{-1}\right)$, hypocalcaemia $\left(2.11 \mathrm{mmol} \mathrm{L}^{-1}\right)$, hypernatraemia $\left(150.6 \mathrm{mmol} \mathrm{L}^{-}\right.$ $\left.{ }^{1}\right)$, and hyperammonaemia $\left(175.8 \mu \mathrm{mol} \mathrm{L}^{-1}\right)$. Compensated metabolic acidosis was observed $(\mathrm{pH}$ 7.347, base excess $-7.1 \mathrm{mmol} \mathrm{L}^{-1}$ ), with an anion gap of $20.0 \mathrm{mmol} \mathrm{L}^{-1}$. Complete blood count was normal. Nine hours after the first haemodialysis, we started the second session, and the VPA concentration decreased to $278.5 \mu \mathrm{g} \mathrm{mL}^{-1}$. The patient started to react to painful stimuli (GCS 8). Laboratory findings were normal, except for thrombocytopenia $\left(124 \times 10^{9} \mathrm{~L}^{-1}\right)$. The third haemodialysis session started 12 hours later. This session, like the previous one, used the Fresenius F6HPS dyaliser. VPA concentration decreased to $61.7 \mu \mathrm{g} \mathrm{mL}^{-1}$ (which is within the therapeutic range). The patient's level of consciousness and mental status were now normal. Electroencephalogram was dysrythmic and mildly decelerated. Laboratory findings were also normal, except, again, for thrombocytopenia $\left(53 \times 10^{9} \mathrm{~L}^{-1}\right)$. Later, when VPA concentration decreased to $49.8 \mu \mathrm{g} \mathrm{mL}^{-1}$, the patient was transferred from the intensive care unit to a neuropaediatric facility. On day 4 , she was discharged home, following psychiatric and neurological assessment. Psychiatric assessment revealed that the attempted suicide was a reaction to a family quarrel and, except for supportive psychological therapy no drugs were administered.

\section{DISCUSSION}

Acute valproate overdose is usually benign. Valproate causes mild toxicity, with lethargy and drowsiness as common symptoms (1). Severe overdose has been associated with respiratory distress, impairment of the liver function, hypoglycaemia, hypocalcaemia, hypernatraemia, hyperammonaemia, direct bone marrow suppression leading to aplastic anaemia or peripheral cytopenia affecting one or more cell lines, renal insufficiency, metabolic acidosis, and severe hypothermia (5-7). Some of this had been observed in our patient. Hypotension, coma, cerebral oedema, multiorgan system failure, and death may also occur $(1,8)$.

To control the acute symptoms of VPA overdose, we started treatment with naloxone boluses. VPA increases brain concentration of gamma-aminobutyric acid (GABA) through various mechanisms. Naloxone has been shown to reverse the VPA blockade of GABA uptake by cells, thereby reversing VPA-mediated inhibition of neuronal firing, although the exact mechanism is unknown (9). However, this did not result in any notable improvement. Some authors suggest that standard-dose naloxone may be ineffective in massive overdose (VPA concentrations $\left.>1000 \mu \mathrm{g} \mathrm{mL}^{-1}\right)$ (2).

VPA has a low volume of distribution and is a relatively small molecule. It is up to $95 \%$ bound to plasma proteins when blood concentrations reach $90 \mu \mathrm{g} \mathrm{mL}^{-1}$ to $100 \mu \mathrm{g} \mathrm{mL}^{-1}$, with decreased binding as concentrations exceed the therapeutic range due to saturation of protein binding sites (4). At VPA concentrations of $300 \mu \mathrm{g} \mathrm{mL}^{-1}$, only $35 \%$ of the drug is protein-bound. At this point, haemodialysis may be beneficial. Our patient's clinical improvement correlated with the use of haemodialysis. For the periods during which the second and the third haemodialysis session was performed, calculated VPA half-life was 5.1 and 6.2 hours, respectively. In between the first and the second session and after the third session, it was 11.3 and 22.6 hours, respectively. Not consistent with this is the period of the first session whose calculated VPA half-life was 13.2 hours. The initial VPA blood concentration was $1320 \mu \mathrm{g} \mathrm{mL}^{-1}$. However, four hours later the clinical condition worsened and, without rechecking the VPA concentration, the first haemodialysis was started. We believed that at that point the VPA level was even higher because of delayed toxicity (10). A threshold level for initiating haemodialysis is not set, but it is proposed that haemodialysis should be considered for any patient with a significantly reduced level of consciousness and elevated VPA concentration (3, 4).

To our knowledge, this is the case with the highest ever reported serum VPA concentration in children aged 16 or less. We have demonstrated the efficacy of haemodialysis and recommend it as a treatment of choice for life-threatening acute VPA overdose.

\section{REFERENCES}

1. Spiller HA, Krenzelok EP, Klein-Schwartz W. Multicenter case series of valproic acid ingestion: serum concentrations and toxicity. J Toxicol Clin Toxicol 2000;38:755-60. 
2. Roberge RJ, Francis EH $3^{\text {rd }}$. Use of naloxone in valproic acid overdose: case report and review. J Emerg Med 2002;22:67-70.

3. Dharnidharka VR, Fennell RS $3^{\text {rd }}$, Richard GA. Extracorporeal removal of toxic valproic acid levels in children. Pediatr Nephrol 2002;17:312-5.

4. Singh SM, McCormick BB, Mustata S, Thompson M, Prasad GV. Extracorporeal management of valproic acid overdose: A large regional experience. J Nephrol 2004; 17:43-9.

5. Seger DL. Anticonvulsants. In: Haddad LM, Shannon MW, Winchester JF, editors. Clinical management of poisoning and drug overdose. $3^{\text {rd }}$ edition. Philadelphia: WB Saunders; 1998. p. 655-63.
6. Acharya S, Bussel JB. Hematologic toxicity of sodium valproate. J Pediatr Hematol Oncol 2000;22:62-5.

7. Robinson P, Abbott C. Severe hypothermia in association with sodium valproate overdose. NZ Med J 2005;118:U1681.

8. Unal E, Kaya U, Aydin K. Fatal valproate overdose in a newborn baby. Hum Exp Toxicol 2007;26:453-6.

9. Hyden H, Cupello A, Palm A. Naloxone reverses the inhibition by sodium valproate of GABA transport across Deiters neuronal plasma membrane [letter]. Ann Neurol 1987;21:416-7.

10. Ingels M, Beauchamp J, Clark RF, Williams SR. Delayed valproic acid toxicity: a retrospective case series. Ann Emerg Med 2002;39:616-21. 


\section{Sažetak}

\section{USPJEŠNO LIJEČENJE TEŠKOG TROVANJA VALPROATOM S POMOĆU HEMODIJALIZE}

Trovanje valproatom sve je češći klinički problem. Najčešći simptom nađen kod trovanja je depresija središnjega živčanog sustava koja može dovesti do kome i smrti. Trovanje se teško liječi jer antidot ne postoji. Prikazujemo slučaj 16-godišnje djevojke koja se otrovala valproatom. U početku je liječena naloksonom, ali nije došlo do poboljšanja. Postala je komatozna s koncentracijom valproata u serumu od $1320 \mu \mathrm{g} \mathrm{mL}^{-1}$. Provođenjem triju ciklusa hemodijalize serumska koncentracija valproata učinkovito je smanjena, nakon čega se razina svijesti vratila na normalu i djevojka se potpuno oporavila.

Prema našim saznanjima, ovo je slučaj s najvišom izmjerenom serumskom koncentracijom valproata u djece od 16 godina ili manje. Na osnovi dobivenih rezultata preporučujemo uporabu hemodijalize u liječenju teških trovanja valproatom u djece.

KLJUČNE RIJEČI: depresori središnjega živčanog sustava, intenziuno liječenje, otrounost, trombocitopenija

\section{CORRESPONDING AUTHOR:}

Julije Meštrović, MD, PhD, Assistant Professor of Paediatrics Paediatric Intensive Care Unit, Department of Paediatrics University Hospital Split Spinčićeva 1, 21000 Split, Croatia E-mail:julije.mestrovic@st.t-com.hr 